\title{
Evaluation of Novel Groups of Insecticides against Leaf Folder, Cnaphalcrocis medinalis (Guenee) in Rice Crop
}

\author{
Vimal Kumar and Sanjay Kumar*
}

\author{
SMS (Plant Protection), Krishi Vigyan Kendra, Ujhani, Badaun (U.P.), India \\ *Corresponding author
}

A B S T R A C T

\begin{tabular}{|l|}
\hline Ke y w o r d s \\
Rice leaf folder, \\
Cnaphalcrocis \\
medinalis, Cartap \\
Hydrochloride, \\
Fipronil and \\
Imidacloprid. \\
\hline Article Info \\
\hline Accepted: \\
04 July 2017 \\
Available Online: \\
10 September 2017
\end{tabular}

A field experiment was conducted to evaluation the novel insecticides against leaf folder during Kharif, 2013 \& Kharif, 2014 at Crop Research Station, Masodha of Narendra Deva University of Agriculture and Technology, Kumarganj, Faizabad (U.P.) in Rice crop. The eight treatments including untreated control were taken for experimentation. The experiment was lay out in RBD with three replication comprising Lambda cyhalothrin 5 EC @62.5g a.i/ha, Cartap Hydrochloride 4G @750g a.i/ha, Profenophos 50EC@ 500g a.i/ha, Fipronil 5 SC@ 75g a.i/ha, Imidacloprid 17.8SL @ 25g a.i/ha, Carbofuron 3 G@750g a.i/ha and Monocrotophos 36SL @ 500g a.i /ha for minimizing the incidence of leaf folder, Cnaphalcrocis medinalis (Guenee) in Rice crop. The treatment Fipronil 5 SC @ $75 \mathrm{gm}$ a.i./ha treated plots showed lowest infestation (3.08 and 3.48\%) and gave higher grain yield ( 40.00 and $37.7 \mathrm{q} / \mathrm{ha}$ ) followed by Cartap hydrochloride $4 \mathrm{G}$ (37.50 and 36.10 $\mathrm{q} / \mathrm{ha}$ ) and Carbofuron $3 \mathrm{G}(36.70$ and $35.30 \mathrm{q} / \mathrm{ha})$ as compare to untreated control $(25.80$ and $23.30 \mathrm{q} / \mathrm{ha}$ ), but the highest cost-benefit ratio of (1:11.24 and 1:9.78) was obtained from Imidacloprid 17.8 SL fallowed by Cartap hydrochloride 4 G (1:7.09 and 1:7.75) and Fipronil 5 SC (1:6.04 and 1.62) respectively during 2013 and 2014.

\section{Introduction}

Rice (Oryza sativa L.), is one of the most important staple food for nearly half of the world population. India has the world's largest area under rice with 44.1 million ha and is the second largest producers 105.48 million tons in 2014-15, next to China (Anonymous, 2016). Various biotic and abiotic constraints encountered the rice production and productivity major biotic constraint that causes 21-40 per cent yield loss. Insects alone cause about $30 \%$ yield loss in rice every year by attacking almost all the aerial parts of the crop plants as well as root system in soil (Prakash and Rao, 2003). Among the various insect-pests damaging the rice crop stem borer, gall midge, brown plant hopper and leaf folder are major pest in India (Anonymous, 2003).

Insect-pests damage rice crop at different stages of crop growth of which leaf feeding insect Cnaphalcrocis medinalis (Guenee) is of major importance because of its ability to defoliate or to remove the chlorophyll content of the leaves resulting considerable reduction in yield.

The yield loss was recorded from 30-80 per cent due to leaf folder epidemic situation (Rani et al., 2007). 


\section{Materials and Methods}

The experiments were conducted at Crop Research Station (CRS), Masodha of Narendra Deva University of Agriculture and Technology, Kumarganj, Faizabad-224 229 (U.P.) as well as farmers' fields of surrounding villages of Research Centre under irrigated condition. The experiments were executed under Randomized Block Design (RBD) with three replication in plot size measuring 5 x 3.9 sq.m during Kharif, 2013 and 2014. The 25 days old seedling of variety Pusa Basmati-1 was taken for experimentation. The spacing between plant to plant $15 \mathrm{~cm}$ and row to row $20 \mathrm{~cm}$ were maintained. All recommended agronomical practices were adopted to raise a good crop. Eight treatments comprising Lambda cyhalothrin 5 EC @ $62.5 \mathrm{~g}$ a.i/ha, Cartap Hydrochloride 4G @ 750g a.i/ha, Profenophos 50EC@500g a.i/ha, Fipronil 5 SC@75g a.i/ha, Imida cloprid 17.8SL @25g a.i/ha, Carbofuron 3 G@750g a.i/ha, Monocrotophos 36SL @ 500g /ha including untreated control were taken for comparison.

The insecticides were applied as and when the pest population reached at their ETL (Economic threshold level) with their respective doses with the help of Knapsack sprayer. The observations on damage caused by leaf folder were recorded at one day before and 3, 10 and 15 days after treatment. The total number of tillers, number of leaves and total damaged leaves (1/3 part folded) were counted on 10 randomly selected hills in each plot for calculating the damaged leaves percent with following formula.

Leaf folder damage $(\%)=\frac{\text { Totalnumber of damaged leaves } / 5 \text { hills }}{\text { Totalnumber of leaves } / 5 \text { hills }} X 100$

The rice crop was harvested plot wise at maturity by excluding two border rows around each plot. The grain weighted as $\mathrm{kg} / \mathrm{plot}$ with the help of balance and converted into $\mathrm{q} / \mathrm{ha}$ for calculating economics of the treatments. The economics of treatment was calculated in terms of cost: benefit ratio on the basis of pooled data of grain yield. The net income of each treatment over the untreated control was calculated based on market price of grain. The cost benefit ratio was computed by using the following formula:

Cost : benefit ratio $=\frac{\text { Monetary gain over control }(\mathrm{Rs} / \mathrm{ha})}{\text { Cost of plant protection }(\mathrm{Rs} / \mathrm{ha})}$

\section{Results and Discussion}

The experimental findings obtained on during the Kharif, 2013 and Kharif, 2014 revealed that all the treatments were significantly effective in reducing the leaf infestation in rice as compare to the control have been discussed.

\section{Leaf damage}

During Kharif, 2013 the leaf damage at three days after I spraying of insecticide, the damage per cent varied from 9.16 to 11.85 per cent, all the treatments were found effective and significantly superior over the control. The minimum per cent leaf damage (9.16 per cent) was recorded in Lamda cyhallothrin 5EC treated plot which was significantly superior over Profenophos 50EC (9.57) followed by Imidacloprid 17.8SL (10.10), Corbofuron 3G (10.13), Monocrotophos 36SC (10.28), Fipronil 5SC (10.35), Cartap hydrochloride 4G (10.83) treated plot as compared with untreated (11.85) control (Table 1).

After 15 DAS the damage per cent ranged from 5.35 to 15.26 per cent. The minimum incidence of per cent leaf damage by leaf folder (5.35) was observed in Fipronil 5SC treated plot followed by Imidacloprid 17.8SL (5.87), Cartap hydrochloride 4G (6.26), Carbofuron 3G (6.74), Monocrotophos 36SC 
(7.13), Profenophos 50EC (7.22) and Lamda cyhallothrin 5EC (7.50) which showed significantly superior over control. The Fipronil 5SC and Imidacloprid 17.8SL treated plot were found at par with each other.

leaf damage at three days after IInd application of the insecticides, The Cartap hydrochloride $4 \mathrm{G}$ treated plots registered the minimum per cent leaf damage (5.13) at three days after second application, which was found significantly superior over rest of the treatments.

The Lamda cyhallothrin 5EC (5.13) and Fipronil 5SC (5.35) treated plot were at par and the Fipronil 5SC and Imidacloprid 17.8 SL treated plot were found at par with each other, but differed significantly from rest of the treatments. All the treatments at 3 DAS were found significantly superior over the control (18.07).

The per cent leaf damage at 15 DAS of the treatments ranged from 2.85 to 25.68 per cent. All treatments showed significantly superior over control. The minimum was also observed in Imidacloprid 17.8 SL (2.85) treated plots.

The Fipronil 5 SC (3.08) and Cartap hydrochloride $4 \mathrm{G}$ (3.39) treated plots were at par, but differed significantly with Corbofuron 3G (3.83), Monocrotophos 36 EC (4.26), Profenophos 50EC (4.72) Lamda cyhallothrin 5EC (4.92). All treatments were found significantly superior over control.

During Kharif, 2014, the $\mathrm{I}^{\text {st }}$ application of insecticides, The per cent leaf damage recorded at 3 DAS varied from 13.71 to 17.80 per cent.The minimum per cent leaf damage (13.71) was observed in Lamda cyhallothrin 5EC treated plots, which differed significantly from Profenophos 50EC (14.40), Carbofuron 3G (15.39), Monocrotophos 36 EC (15.50), Fipronil 5 SC (15.81), Imidacloprid 17.8 SL
(15.97) and Cartap hydrochloride 4 G (16.45) treated plots as compared with untreated control (17.80). The Fipronil 5 SC was at par with Imidacloprid 17.8 SL and Carbofuron 3G (15.39), Monocrotophos 36 EC (15.50) was also found at par (Table 2).

The per cent leaf damage recorded at 15 DAS of insecticide ranged from 7.51 to 20.16 per cent. The Fipronil 5 SC treated plots recorded the minimum leaf damage followed by Imidacloprid 17.8 SL (8.21), Cartap hydrochloride $4 \mathrm{G}$ (8.82), Carbofuron 3G (9.65), Monocrotophos 36 EC (9.78), Profenophos 50EC (9.95) and Lamda cyhallothrin 5EC (10.12) The findings of the present studies are in conformity of the result of Aulakh, (2016).

The per cent damage ranged from 5.59 to 23.20 per cent after 3 DAS after IInd application of insecticides. The plots treated with Carbofuron $3 \mathrm{G}$ registered minimum leaf damage percentage at 3 DAT after the second spray of insecticide followed by Lamda cyhallothrin 5EC (8.15), Profenophos 50EC (8.50), Imidacloprid 17.8 SL (8.80), Fipronil 5 SC (9.00), Monocrotophos 30 EC (9.42) and Cartap hydrochloride 4G (9.54). Monocrotophos 30 EC and Cartap hydrochloride $4 \mathrm{G}$ were found at par. All treatments were found significantly superior over the control in which (23.20) per cent leaf damage observed (Table 2).

The damage per cent was recorded at 15 DAT of the treatment ranged from 3.36 to 27.70 per cent. The minimum per cent leaf damage was observed in Imidacloprid 17.8 SL treated plot and was at par with Fipronil 5 SC (3.48), but differed significantly from rest of the treatments. Cartap hydrochloride 4G (3.86), Carbofuron 3G (4.39), Monocrotophos 30 EC (4.72), Lamda cyhallothrin 5EC (5.36) and Profenophos 50EC (5.38) was found superior over control (27.60). 
Table.1 Evaluation of different insecticides against rice leaf folder of rice cv. Pusa basmati-1 during Kharif, 2013

\begin{tabular}{|c|c|c|c|c|c|c|c|c|c|}
\hline \multirow{3}{*}{$\begin{array}{c}\text { S. } \\
\text { No. }\end{array}$} & \multirow{3}{*}{ Treatments } & \multirow{3}{*}{$\begin{array}{c}\text { Dose } \\
\text { a.i./ha }\end{array}$} & \multicolumn{7}{|c|}{ Leaf damage $(\%)$} \\
\hline & & & \multirow{2}{*}{$\begin{array}{c}\text { Pre } \\
\text { Treatment }\end{array}$} & \multicolumn{3}{|c|}{$1^{\text {st }}$ Spraying } & \multicolumn{3}{|c|}{$2^{\text {nd }}$ Spraying } \\
\hline & & & & 3 DAS* & 10 DAS* & 15 DAS* & 3 DAS* & 10 DAS* & 15 DAS* \\
\hline $\mathbf{T}_{1}$ & Lambda cyhalothrin 5EC & 62.5 & 11.60 & 9.16 & 7.13 & 7.50 & 5.13 & 5.05 & 4.92 \\
\hline $\mathbf{T}_{2}$ & Cartap hydrochloride $4 G$ & 750 & 11.50 & 10.83 & 8.42 & 6.26 & 6.24 & 4.19 & 3.39 \\
\hline $\mathbf{T}_{3}$ & Profenophos 50EC & 500 & 11.61 & 9.57 & 8.36 & 7.22 & 5.35 & 5.07 & 4.72 \\
\hline $\mathbf{T}_{4}$ & Fipronil 5SC & 75 & 11.51 & 10.35 & 7.03 & 5.35 & 5.75 & 4.10 & 3.08 \\
\hline $\mathbf{T}_{5}$ & Imidachloprid 17.8SL & 25 & 11.53 & 10.1 & 7.85 & 5.87 & 5.49 & 3.92 & 2.85 \\
\hline $\mathbf{T}_{6}$ & Carbofuron 3G & 25 & 11.16 & 10.13 & 7.35 & 6.74 & 6.30 & 4.34 & 3.83 \\
\hline $\mathbf{T}_{7}$ & Monocrotophos 36SC & 750 & 10.87 & 10.28 & 8.62 & 7.13 & 6.11 & 5.03 & 4.26 \\
\hline $\mathbf{T}_{8}$ & Control & - & 11.03 & 11.85 & 13.26 & 15.26 & 18.07 & 20.62 & 25.68 \\
\hline \multicolumn{2}{|c|}{ SEm \pm} & - & 0.31 & 0.30 & 0.20 & 0.20 & 0.21 & 0.20 & 0.21 \\
\hline \multicolumn{2}{|c|}{ CD at $5 \%$} & - & 0.93 & 0.90 & 0.62 & 0.61 & 0.64 & 0.61 & 0.63 \\
\hline
\end{tabular}

DAS*- Days After Spraying.

Table.2 Evaluation of different insecticides against rice leaf folder of rice cv. Pusa basmati-1 during Kharif, 2014

\begin{tabular}{|c|c|c|c|c|c|c|c|c|c|}
\hline \multirow{2}{*}{$\begin{array}{c}\text { S. } \\
\text { No. }\end{array}$} & \multirow[b]{2}{*}{ Treatments } & \multirow{2}{*}{$\begin{array}{c}\text { Dose } \\
\text { a.i./ha }\end{array}$} & \multicolumn{7}{|c|}{ Leaf damage $(\%)$} \\
\hline & & & $\begin{array}{c}\text { Pre } \\
\text { Treatment }\end{array}$ & \multicolumn{3}{|c|}{$1^{\text {st }}$ Spraying } & \multicolumn{3}{|c|}{$2^{\text {nd }}$ Spraying } \\
\hline $\mathbf{T}_{1}$ & Lambdacyhellathrin 5EC & 62.5 & 15.17 & 13.71 & 11.06 & 10.12 & 8.15 & 6.50 & 5.36 \\
\hline $\mathbf{T}_{3}$ & Profenophos 50EC & 500 & 16.44 & 14.40 & 12.37 & 9.95 & 8.5 & 6.36 & 5.38 \\
\hline $\mathbf{T}_{4}$ & Fipronil 5SC & 75 & 16.97 & 15.81 & 11.38 & 7.51 & 9.00 & 5.21 & 3.48 \\
\hline $\mathbf{T}_{5}$ & Imidachloprid 17.8SL & 25 & 16.44 & 15.97 & 12.15 & 8.21 & 8.8 & 4.95 & 3.36 \\
\hline $\mathbf{T}_{8}$ & Control & - & 16.85 & 17.80 & 18.98 & 20.16 & 23.20 & 25.35 & 27.60 \\
\hline \multicolumn{2}{|c|}{ SEm \pm} & - & 0.71 & 0.29 & 0.29 & 0.21 & 0.31 & 0.41 & 0.41 \\
\hline \multicolumn{2}{|c|}{ CD at $5 \%$} & - & 2.14 & 0.88 & 0.87 & 0.64 & 0.95 & 1.24 & 1.25 \\
\hline
\end{tabular}

DAS*- Days After Spraying 
Table.3 Cost: benefit ratio of the treatments against leaf folder during 2013

\begin{tabular}{|c|c|c|c|c|c|c|c|c|c|c|c|}
\hline $\begin{array}{l}\text { S. } \\
\text { No. }\end{array}$ & Treatments & $\begin{array}{c}\text { Dose } \\
\text { a.i./ha }\end{array}$ & $\begin{array}{l}\text { Yield } \\
\text { q/ha }\end{array}$ & Dose/ ha & $\begin{array}{c}\text { Cost of } \\
\text { insecticides } \\
\text { Rs./L/Kg } \\
\end{array}$ & $\begin{array}{c}\text { Cost of } \\
\text { treatments } \\
\text { Rs./ha } \\
\end{array}$ & $\begin{array}{l}\text { Additional } \\
\text { yield (q/ha) }\end{array}$ & $\begin{array}{c}\text { Value of } \\
\text { Additional } \\
\text { yield Rs./ha }\end{array}$ & $\begin{array}{c}\text { Gross } \\
\text { Income } \\
\text { Rs./ha } \\
\end{array}$ & $\begin{array}{c}\text { Net } \\
\text { Income } \\
\text { Rs./ha } \\
\end{array}$ & $\begin{array}{c}\text { C:B } \\
\text { Ratio }\end{array}$ \\
\hline $\mathbf{T}_{1}$ & $\begin{array}{l}\text { Lambdacyhellathrin } \\
\text { 5EC }\end{array}$ & 62.5 & 30.4 & $1.25 \mathrm{~L}$ & $600 /-$ & 2300 & 4.6 & 9200 & 60800 & 6900 & $1: 4.0$ \\
\hline $\mathbf{T}_{2}$ & $\begin{array}{l}\text { Cartap hydrochloride } \\
\text { 4G }\end{array}$ & 7.50 & 37.5 & $18.75 \mathrm{Kg}$ & $80 /-$ & 3300 & 11.7 & 23400 & 75000 & 20100 & $1: 7.09$ \\
\hline $\mathbf{T}_{3}$ & Profenophos 50EC & 500 & 30.8 & $1.0 \mathrm{~L}$ & $700 /-$ & 2200 & 5.0 & 1000 & 61600 & 7800 & $1: 4.54$ \\
\hline $\mathbf{T}_{5}$ & Imidachloprid 17.8SL & 25 & 32.50 & $0.14 \mathrm{~L}$ & $1400 /-$ & 1192 & 6.7 & 13400 & 65000 & 12208 & $1: 11.24$ \\
\hline $\mathbf{T}_{6}$ & Carbofuron 3G & 25 & 36.7 & $25 \mathrm{~kg}$ & $80 /-$ & 4300 & 10.9 & 21800 & 73400 & 17500 & $1: 5.06$ \\
\hline $\mathbf{T}_{7}$ & Monocrotophos 36SC & 750 & 31.7 & $1.5 \mathrm{~L}$ & $600 /-$ & 2600 & 5.9 & 11800 & 63400 & 9200 & $1: 4.53$ \\
\hline $\mathbf{T}_{8}$ & Control & - & 25.8 & - & 3.100 & - & - & - & 51600 & - & - \\
\hline
\end{tabular}

Labour charge for spray $=$ Rs $150 \times 2=300$

Labour charge for broadcasting $=$ Rs $150 \times 1=150$

Sprayer charge $=$ Rs $50 \times 2=100$

Product price $=$ Rs 2000/ Quintal

Table.4 Cost: benefit ratio of the treatments against leaf folder during 2014

\begin{tabular}{|c|c|c|c|c|c|c|c|c|c|c|c|}
\hline $\begin{array}{l}\text { S. } \\
\text { No. }\end{array}$ & Treatment & $\begin{array}{c}\text { Dose } \\
\text { (a.i./ha) }\end{array}$ & $\begin{array}{c}\text { Quantity } \\
\text { required/ha }\end{array}$ & $\begin{array}{c}\text { Cost of } \\
\text { insecticides } \\
\text { (Rs.) }\end{array}$ & $\begin{array}{c}\text { Cost of } \\
\text { Treatments } \\
\text { (Rs.) } \\
\end{array}$ & $\begin{array}{l}\text { Yield } \\
\text { (q/ha) }\end{array}$ & $\begin{array}{l}\text { Additional } \\
\text { yield (q/ha) }\end{array}$ & $\begin{array}{c}\text { Value } \\
\text { Additional } \\
\text { yield (Rs.) }\end{array}$ & $\begin{array}{c}\text { Gross } \\
\text { Income } \\
\text { (Rs.) } \\
\end{array}$ & $\begin{array}{c}\text { Net } \\
\text { Income } \\
\text { (Rs.) } \\
\end{array}$ & $\begin{array}{c}\text { C:B } \\
\text { Ratio }\end{array}$ \\
\hline $\mathbf{T}_{1}$ & Lambdacyhellathrin 5EC & 62.5 & $1.25 \mathrm{~L}$ & $600 /-$ & 2300 & 29.6 & 6.3 & 12600 & 59200 & 10300 & $1: 5.47$ \\
\hline $\mathbf{T}_{2}$ & Cartap hydrochloride $4 \mathrm{G}$ & 7.50 & $18.75 \mathrm{Kg}$ & $80 /-$ & 3300 & 36.1 & 12.8 & 25600 & 72200 & 22300 & $1: 7.75$ \\
\hline $\mathbf{T}_{3}$ & Profenophos 50EC & 500 & $1.0 \mathrm{~L}$ & $700 /-$ & 2200 & 28.2 & 4.9 & 9800 & 56400 & 7600 & $1: 4.45$ \\
\hline $\mathbf{T}_{4}$ & Fipronil 5SC & 75 & $1.5 \mathrm{~L}$ & $1300 /-$ & 4700 & 37.7 & 14.4 & 28800 & 75400 & 24100 & $1: 6.12$ \\
\hline $\mathbf{T}_{5}$ & Imidachloprid 17.8SL & 25 & $0.14 \mathrm{~L}$ & $1400 /-$ & 1192 & 29.16 & 5.83 & 11660 & 58320 & 10468 & $1: 9.78$ \\
\hline $\mathbf{T}_{6}$ & Carbofuron 3G & 25 & $25 \mathrm{~kg}$ & 80/- & 4300 & 35.3 & 12.0 & 24000 & 70600 & 17900 & $1: 5.58$ \\
\hline $\mathbf{T}_{7}$ & Monocrotophos 36SC & 750 & $1.5 \mathrm{~L}$ & $600 /-$ & 2600 & 31.3 & 8.0 & 16000 & 62600 & 13400 & $1: 6.15$ \\
\hline $\mathbf{T}_{8}$ & Control & - & - & - & - & 23.3 & - & - & 46600 & - & - \\
\hline
\end{tabular}

Labour charge for spray $=$ Rs $150 \times 2=300$

Labour charge for broadcasting $=$ Rs $150 \times 1=150$

Sprayer charge $=$ Rs 50x2 $=100$

Product price $=$ Rs 2000/ Quintal 


\section{Grain yield}

The grain yield obtained in different treatments during both the Kharif, 2013 and 2014 have been presented in (Tables 3 and 4). During Kharif 2013, the data on grain yield in all treatments were found significantly superior over check (untreated control). Fipronil 5 SC treated plots gave maximum grain yield (40.00 $\left.\mathrm{q} \mathrm{ha}^{-1}\right)$, followed by Cartap hydrochloride $4 \mathrm{G}\left(37.50 \mathrm{q} \mathrm{ha}^{-1}\right)>$ Carbofuron 3G (36.70 q ha $\left.{ }^{-1}\right)>$ Imidacloprid 17.8 SL (32.50 q ha $\left.{ }^{-1}\right)>$ Monocrotophos 36 EC (31.70 $\left.\mathrm{q} \mathrm{ha}^{-1}\right)>$ Profenophos 50EC (30.80 q ha $\left.{ }^{-1}\right)>$ Lamda cyhallothrin 5EC (30.40 $\left.\mathrm{q} \mathrm{ha}^{-1}\right)>$ and untreated control $\left(25.80 \mathrm{q} \mathrm{ha}^{-1}\right)$. Similar trend was noted during Kharif, 2014 also. The maximum yield (37.70 $\left.\mathrm{q} \mathrm{ha}^{-1}\right)$ was recorded in Fipronil 5 SC treated plots, which differed significantly from Cartap hydrochloride 4G, Carbofuron 3G, Monocrotophos 36 EC, Lamda cyhallothrin 5EC, Imidacloprid 17.8 SL and Profenophos 50EC, while the grain yield was found 36.10, 35.30, 31.60, 29.60, 29.16 and $28.20 \mathrm{q} \mathrm{ha}^{-1}$ respectively. The minimum grain yield was recorded in untreated control (23.30 q ha $\left.{ }^{-1}\right)$. The findings of the present studies are in conformity of the result of Panda et al., (2004) and Singh et al., (2005). The maximum benefit-cost ratio was obtained in plots treated with Imidacloprid 17.8 SL (1:11.24) followed by Cartap hydrochloride $4 \mathrm{G}$ with (1:7.09). The benefitcost ratios of other treatments observed in descending order were as follows: Fipronil 5 SC (1:6.04), Carbofuron 3G (1:5.06), Profenophos 50EC (1:4.54), Monocrotophos (1:4.53) and Lamda cyhallothrin 5EC (1:4.00) during Kharif, 2013. However, during Kharif, 2014 the maximum benefit: cost ratio was obtained in plots treated with Imidacloprid 17.8 SL (1:9.78) followed by Cartap hydrochloride $4 \mathrm{G}$ with (1:7.75). Panda et al., (2004), Singh et al., (2005), Singh et al., (2010), Dhaka et al., (2011) and Dhaka et al., (2012) have also reported Fipronil 5SC as most effective insecticide to check the leaf folder incidence.

\section{Acknowledgements}

The authors are thankful to the Director of Research, Narendra Dev University of Ag. \& Tech., Kumargang, Faizabad and Head, Department of Entomology, College of Agriculture for the unstinted support and other research facilities provided to carry out the investigation.

\section{References}

Anonymous, 2003. Progress Report 2002, Vol.-2 (Entomology and Pathology). All India Coordinated Rice Improvement project, Directorate of Rice Research, Rajendra Nagar, Hyderabad, A.P, India. pp. 36-39.

Anonymous, 2016. Annual Report 2016-17, Department of Agriculture, Cooperation \& Farmers Welfare Ministry of Agriculture \& Farmers Welfare Government of India Krishi Bhawan, New Delhi(India). pp. 194.

Aulakh, S.S., Randhawa, H.S. and Singh, M. 2016. Bioefficacy of insecticides for management of stem borer and leaf folder on paddy in Punjab. Agric. Sci. Digest., 36 (3): 224-227.

Dhaka, S. S., Prajapati, C. R., Singh, D. V. and Singh, R. 2011. Field evaluation of insecticides and bio-pesticides against rice leaf folder, Cnaphalocrocis medinalis (Guenee). Annals of Plant Protection Sciences 19(2):324-326.

Dhaka, S.S., Singh, G., Yadav, A., Ali, N. and Singh, D. V. 2012. Evaluation of some novel insecticides against rice leaffolder, Cnaphalocrocis medinalis (Guenee). Progressive Agriculture 12(2):360-364.

Panda, S.K., Nayak, S.K. and Behera, U.K. 2004. Field efficacy of some 
insecticides against the rice leaf folder, Cnaphalocrocis medinalis (Guenee) and whorl maggot, Hydrellia philippina (Ferino). Pest Management and Economic Zoology 7(1): 55-59.

Rani, W.B., Amutha, R., Muthulakshmi, S., Indra, K. and Mareesawri, P. 2007. Diversity of rice leaf folders and their natural enemies. Resarch Journal of Agriculture and Biological Science 3(5): 394-397.
Singh, A.K., and Singh, R.N. 2005. Screening of rice (Oryza sativa L.) germplasm resistant to leaf folder (Cnaphalocrocis medinalis Guen). Journal of Applied Biology 11(1/2):10-13.

Singh, D., Bhatnagar, P., Om, H. and Sheokhand, R. S. 2010. Efficacy of insecticides against stem borer and leaf hopper environment and ecology, 20(2): 884-886.

\section{How to cite this article:}

Vimal Kumar and Sanjay Kumar. 2017. Evaluation of Novel Groups of Insecticides against Leaf Folder, Cnaphalcrocis medinalis (Guenee) in Rice Crop. Int.J.Curr.Microbiol.App.Sci. 6(9): 442-448. doi: https://doi.org/10.20546/ijcmas.2017.609.053 